\title{
Reseña de Martínez de Pisón, Eduardo; Ortega Cantero, Nicolás (Eds.). (2019). Paisaje y turismo. Madrid: Universidad Autónoma de Madrid; Fundación Duques de Soria de Ciencia y Cultura Hispánica
}

\author{
Patricia Eugenia Olivera MarTínez \\ Facultad de Filosofía y Letras, \\ Universidad Nacional Autónoma de México \\ México
}

A la memoria del Dr. Miguel Ángel Troitiño Vinuesa, Universidad Complutense de Madrid, Facultad de Geografia e Historia

Dos temas relevantes sin duda, paisaje y turismo, se conjugan en este libro a partir de la diversidad y el consumo de los paisajes naturales, de las ciudades y los territorios rurales, transformándose profundamente por la actividad turística, altamente demandante de expresiones territoriales cargadas de imágenes, experiencias y del acercamiento a lo lúdico y novedoso. Los capítulos también entregan la perspectiva patrimonial de las riquezas naturales y de la historia, cristalizada en las morfologías urbanas, en sus centros históricos y paisajes tan cambiantes como vulnerables que guardan memorias para ser contadas.

El libro Paisaje y turismo es producto del seminario organizado por la Fundación Duques de Soria, realizado en noviembre de 2018. Está constituido con investigaciones acerca de los paisajes patrimoniales naturales, literarios y urbanos. El primer capítulo, “Cien años de parques nacionales: Covadonga y Ordesa”, de Eduardo Martínez Pisón, nos remite a aquellos espacios que en su nombre profesan la pertenencia patrimonial "parque nacional", cuyas características naturales sobresalientes buscan ser catalogadas, disfrutadas, estudiadas y esencialmente protegidas. El segundo trabajo, de Nicolás Ortega Cantero, "Paisaje, fotografía y turismo. Las primeras imágenes fotográficas del oeste de los Estados Unidos", nos relata las transformaciones radicales de las sociedades, modos de vida y poblamiento. El capítulo de Marcella Schmidt, "History of the Landscape Gaze: The Image of Tourism in the Maldives", retoma el mito de la isla tropical paradisiaca, más allá de un espacio geográfico, un lugar simbólico y mitológico, de las cosmogonías en un medio acuoso donde surge una isla, un viaje de retorno a la naturaleza, pero también con distopias colonialistas. El capítulo de Omar Monca- 


\section{$74 \square$ RESEÑAS}

da, "Paisaje y turismo. El caso de Barrancas del Cobre en Chihuahua, México", nos remite al turismo de aventura con el componente paisajístico natural de esos impresionantes paisajes recorridos incansablemente por los pueblos rarámuri, trashumantes. Sigue el trabajo "Pression touristique et évolutions paisagères du litoral landais", de Chistine Bouisset e Isabelle Degrémont. Por otro lado, María del Carmen Meza refiere la flora característica de la diversidad de paisajes en "Jardines botánicos. Paisaje recuperado para el turismo", jardines cuyos propósitos han cambiado desde su origen, actualmente pedgagógico y conservacionista. En torno a los paisajes literarios, Luis Felipe Cabrales Barajas, en "México en Julio Verne: itinerario paisajístico, de Acapulco al Popocatépetl", nos habla del geógrafo fabulador Julio Verne, cuyas obras intentaron atraer a los jóvenes a la geografía entretejiendo arte y ciencia, reconstruyendo los paisajes con imaginación, cartografías de paisajes mentales y la información científica existente, una de cuyas fuentes fue Humboldt. Entre los conspicuos lectores de Verne se hallan Yi Fu Tuan y Carl Sagan. El autor también nos habla del periplo que invisibilizó la novela de Verne Un drama en México, publicada en 1852 en español, con 24 ediciones, incluyendo una prologada por Carlos Monsivais en 1976. Otro capítulo de paisaje literario es "Tourisme litteraire et paysage. L'example des pays de L'ancienne Indochine francaise", de Jean Yves Puyo.

Los capítulos sobre paisajes urbanos inician con Amaya Larrucea, "Paisajes arqueológicos e imaginarios del turismo en Teotihuacan (1805-1963)", ciudad atrayente para exploradores y naturalistas, entre ellos Alejandro de Humboldt y el coleccionista William Bullock, residente entre 1822-1823; acompañan litografías que contribuyeron a la formación del imaginario del México antiguo. En la aproximación a la ciudad y sus paisajes, Dolores Brandis e Isabel del Río nos sumergen en el icónico barrio histórico de "Lavapiés vulnerable y el golpe del turismo. La afección de un paisaje urbano histórico", sitio de reunión de vecinos alrededor de la fuente de Lavapiés situada en un bivio, barrio popular densificado con viviendas interiores en corralas, cuartelillos, casas de corredor de clase obrera dentro del casco antiguo de Madrid. El barrio pasó por fases de precariedad y abandono, a la reinversión y turistización. Particularmente, en 2004, el plan estratégico de revitalización se orientó al turismo y las obras ocasionaron especulación, elevación de precios de inmuebles y desplazamiento social. Se ha convertido en un barrio multinacional, de okupas, artistas y grupos contra la transformación de viviendas en hoteles y bares.

Con especial atención, esta reseña se dirige hacia el capítulo de Miguel Ángel Troitiño, "Dinámicas urbanas, turismo y paisaje: el centro de Madrid", para agradecer y reconocer la obra del gran profesor cuyas contribuciones abarcan líneas de investigación que invitan a potencializarlas, por su gran relevancia para la sociedad. Desde la mirada erudita y educadora del autor sobre el patrimonio histórico, paisajístico y su vinculación con el turismo, este capítulo parte del amplio contexto histórico de la realidad urbana, con cambios dinámicos en profunda tensión de sus actores sociales, actividades y paisajes que ponen de manifiesto que en los centros urbanos se gesta un elevado conflicto de intereses por la apropiación y control de la rentabilidad del es- 
pacio edificado, disputado como recurso turístico. Se acoplan de manera directa y simbólica, nos refiere el autor, las condiciones para el uso y consumo masivo de los espacios centrales, poniendo en riesgo la herencia patrimonial y desdibujándose las identidades por la banalización y homogeneización en esa lógica de terciarización, segregación, turistificación, gentrificación. De allí que Troitiño lance la pregunta acerca del papel que juega el turismo en la ciudad, sus paisajes patrimoniales cargados de símbolos y valoraciones y pone el foco de atención en el nuevo ciclo de cambios en los centros históricos, entendidos desde dos posturas confrontadas. De un lado, la planeación estratégica orientada hacia la competitividad, la marca y el ranking de la ciudad y, por otro lado, la postura crítica - a la que se adhiere Troitiño - evidenciando los procesos negativos.

Nuestro autor plantea una aproximación dialéctica entre el paisaje constitutivo del patrimonio edificado y el turismo; refiere una retrospectiva del papel que ha jugado el turismo en la elevación de la calidad de vida y generando recursos para la conservación patrimonial. Sin embargo, la masificación del turismo incrementa la sustitución residencial por usos terciarios en estrecha correspondencia con franquicias, intereses inmobiliarios y financieros. Troitiño concibe el paisaje urbano por su riqueza morfológica, diversidad social, funcional y cultural, lo que genera una enorme atracción simbólica y pertenencia histórica; nos dice: "Cada paisaje, en su esencia, es heredero del momento histórico de su creación, pero también de las transformaciones que ha ido conociendo a lo largo del tiempo" (217). La carga cultural de los centros históricos requiere entonces el estudio diacrónico comprensivo y explicativo, desde el espacio vivido, las experiencias de residentes y visitantes, orientada por la perspectiva patrimonial y simbólica.

En el segundo apartado "Paisaje urbano y turismo: una dialéctica conflictiva", Troitiño traza una metodología para evaluar los impactos en las estructuras del paisaje, ambiental, del medio edificado, funcional y social, poniendo en el centro del análisis los valores patrimoniales y sus alteraciones, para identificar y tipificar los conflictos, considerando la escalaridad de la ciudad, sus barrios, calles, edificios, plazas, donde ocurre la práctica del turismo de manera transversal y, con ello, la pérdida objetiva y subjetiva de las prácticas sociales en barrios profundamente transformados, como Lavapiés. Además de la elevación de alquileres, los cambios en la población, la desaparición de actividades tradicionales por otras turísticas, hay flujos de inversión que alteran el espacio residencial, de trabajo, e incorporan lecturas distintas del paisaje, sus valoraciones, sentimientos, percepciones. Plantea la noción paisaje urbano "mosaico", sin edificaciones íconicas más importantes que otras, sino un conjunto de paisajes distintivos para proteger y mantener sus rasgos identitarios, incluyendo infraestructuras y entornos periurbanos.

El tercer y cuarto apartados, "Madrid, un destino de turismo urbano expansivo con un centro urbano atractivo" y "La inserción de actividades turísticas en el centro de Madrid: problemáticas e impactos paisajísticos", refieren la extraordinaria oferta patrimonial, histórica y cultural de Madrid, la quinta ciudad europea más visitada. Sus 
grandes avenidas y plazas asientan edificaciones patrimoniales, articuladoras del turismo. El trabajo ofrece mapas detallados de los impactos, entre los que se encuentran la concentración de la vivienda turística en el centro de Madrid (95\%), la oferta gastronómica $(93.5 \%)$, el dinamismo de la apertura de establecimientos en el centro de Madrid entre 2000 y 2016, y las tiendas de marca que homogeneizan los paisajes centrales, concentrando el $95 \%$ de las tiendas. En contraste, la experiencia de la sociedad civil ha propiciado organizaciones, como la Plataforma de Afectados por la Hipoteca, recordándonos el nacimiento del movimiento Indignados $15 \mathrm{M}$, con ocupaciones de las plazas centrales de Madrid en 2011. El quinto apartado, "Intervenciones urbanas: renovación y transformación del paisaje", muestra el flujo del gran capital en el área central, grandes hoteles de lujo mezclados con establecimientos comerciales y vivienda de lujo. Edificios catalogados de gran arquitectura con funciones administrativas son adquiridos por empresas extranjeras para convertirse en centros corporativos de seguros y otros usos. Troitiño refiere este proceso como saqueo al patrimonio; entre otros, analiza el Proyecto Canalejas que, con la salida del banco Santander en 2004 a su nueva sede en La Castellana, dejó siete propiedades promocionadas de manera especulativa por OHL, cambiando todas las ordenanzas de preservación del patrimonio arquitectónico, las que fueron desarrolladas por la firma canadiense Four Seasons.

En las reflexiones finales, Troitiño propone centrar el papel de los gobiernos locales en la materialización de los cambios para garantizar la diversificación funcional, la conservación y recuperación patrimonial que están amenzadas por la liberalización y mercantilización de los bienes patrimoniales. Troitiño llama a "racionalizar la revolución turística que están viviendo las ciudades" (262) pues a pesar de que el suelo edificado es mayormente privado, tiene dimensiones y valores colectivos que no pueden ser subordinados por el turismo. El paisaje urbano es un valor común, colectivo; es un recurso de dimensión patrimonial, cultural y vivencial que puede coexistir con el turismo.

Miguel Ángel Troitiño Vinuesa fue un gran defensor del territorio desde los frentes donde realizó actividades como geógrafo especialista en el patrimonio paisajístico urbano y ambiental (Brandis, del Río y Muñoz, 2020). En su obra destacan investigaciones sobre las siete ciudades y conjuntos históricos - Cuenca (Troitiño, 2002), Toledo, Aranjuez, El Escorial, Atapuerca (Troitiño y Troitiño, 2015)—, defendiendo la acción colectiva para la ordenación del territorio con un fin social, con acciones de liderazgo institucional incluyendo la academia e instancias gubernamentales, proyectando acciones para la territorialización de las políticas y considerando el patrimonio como piedra angular para el desarrollo territorial local (Colegio de Geógrafos, 2006).

Entre otras investigaciones, destaca el proyecto de Ciudades patrimonio de la humanidad de España y México, experiencias comparadas de planificación y gestión, colaborando con la Universidad de Guanajuato y la Universidad de Guadalajara, donde presentó conferencias, impartió seminarios y participó en publicaciones (Cabrales Barajas, 2019; Troitiño et al., 2010) y, asimismo, con El Colegio de Michoacán y el Instituto de Geografía de la UNAM. 
Por unanimidad, el Ayuntamiento de Cuenca en 2020 dedicó un mirador de la Hoz del Huécar al geógrafo Miguel Ángel Troitiño Vinuesa (1947-2020), quien fuera clave para la designación de Ciudad Patrimonio de la Humanidad, el 6 de diciembre de 1996.

\section{Referencias bibliográficas}

Brandis, Dolores; DEL Río, Isabel; MuÑoz, Julio. (2020). "Más de 40 años de amistad, compañerismo y dedicación a la geografía con Miguel Ángel Troitiño Vinuesa". Cuadernos de Ordenación del Territorio, (9), 35- 42. http://clubdebatesurbanos. org/wp-content/uploads/2020/10/DOCUMENTO-FINAL-REVISTA-No9-QUINTA-EPOCA. pdf

Cabrales Barajas, Luis Felipe. (2019). "México. Territorio Troitiño”. Cuadernos de Ordenación del Territorio, (9), Nueva época, 139-146. http://clubdebatesurbanos. org/wp-content/uploads/2020/10/DOCUMENTO-FINAL-REVISTA-No9-QUINTA-EPOCA. pdf

Colegio de Geógrafos. (2006). Manifiesto por una nueva cultura del territorio. Asociación de Geógrafos Españoles. Recuperado 30 de septiembre 2020 de: https:// www.geografos.org/manifiesto-por-una-nueva-cultura-del-territorio/

Troitiño, Miguel A. (2002). "El patrimonio arquitectónico y urbanístico como recurso turístico”. En Joaquín S. García Marchange y María del Carmen Poyato Holgado (Coords.), La función social del patrimonio histórico: El turismo cultural. Cuenca: Ediciones de la Universidad de Castilla-La Mancha. 9-32.

Troitiño, Miguel Ángel; de la Calle, Manuel; Ruiz Lanuza, Agustín; Hiriart, Carlos Alberto (Coords). (2010). Dinámicas funcionales del turismo y sus impactos en las ciudades Patrimonio de la Humanidad. Estudios comparados entre México y España. España: Universidad de Guanajuato.

Troitiño, Miguel Ángel; Troitiño, Libertad. (2015). “Territorio y Sistemas Patrimoniales: La Región Urbana de Madrid”. Ciudad y Territorio: Estudios Territoriales, 47(184), 255-273. https://recyt.fecyt.es/index.php/CyTET/article/view/76408 